\title{
POTENSI PENGEMBANGAN DESA WISATA BERBASIS MASYARAKAT DI DESA GUNUNG SALAK KABUPATEN TABANAN
}

\author{
I Gusti Agung Gde Suryadarmawan') \\ Ni Gst.Ag.Gde Eka Martiningsih' ${ }^{2}$ \\ Ni Putu Sukanteri ${ }^{3}$ ) \\ I Made Suryana ${ }^{4}$ \\ Fakultas Teknik Universitas Mahasaras wati Denpasar ${ }^{1}$ \\ Fakultas Pertanian Universitas Mahasaraswati Denpasar ${ }^{2,3,4}$ \\ Email: psagungsurya@gmail.com ${ }^{1}$,ekamartini@gmail.com², putusukanteri@gmail.com³ \\ decksuryana@gmail.com ${ }^{4}$
}

\begin{abstract}
Tourism is in fact a journey done many times in the same place as well as at different destinations. The meaning of the word tourism is stingray and sightseeing, pari means many times while tourism means visitation. From the meaning of the word then the tourist destination should always be created at any time in order to still have a different attraction for tourists. One of the many developed tourism concepts today is community-based tourism that utilizes natural beauty and local culture as a tourist attraction. The village of Mount Salak located in the District of East Selemadeg Tabanan Regency has a very large opportunities to be developed into a community-based tourism area because it has a natural beauty that is natural with socio-cultural activities are still thick. The development of this village should be accompanied by guidance and empowerment of the community both in the field of economy and businesses that are able to support tourism activities, so as to produce multiplayer effects for the surrounding community. In addition, the structuring of supporting infrastructure facilities, institutional arrangements must be made to strengthen the basis of the formation of community-based tourism.
\end{abstract}

Keywords: community-based tourism, multiplayer effects, community empowerment 


\section{PENDAHULUAN}

\section{Latar Belakang}

Desa identik sebagai basis dari pengembangan pertanian dan lahan pertanian yang luas bahkan tenaga kerja yang melimpah, sehingga berbagai asumsi terhadap desa timbul berdasarkan pemikiran banyak pihak. Pemahaman mengenai berbagai aspek kehidupan sosial dan budaya berjalan kental dengan tradisi pun berjalan semestinya. Di sisi lain permasalahan yang timbul saat ini adalah menurunnya produksi pertanian khusus di wilayah tersebut akibat alih fungsi lahan besar-besaran dan kurangnya air untuk produksi pertanian. Lahan di desa kelihatan jelas telah terjadi alih fungsi yang ditimbulkan oleh berbagai faktor. Salah satu faktor penyebab alaih fungsi lahan kurang nya SDM yang mempunyai pengetahuan dan ketrampilan dalam bidang pertanian serta ketersediaan air yang terbatas menyebabkan ekonomi di desa tersebut sangat rendah. Bertolak dari kondisi ekonomi banyak warga masyarakat yang telah menjual sawah dan lahan pertanian lain ditukar dengan uang sebagai penunjang ekonomi.

Berdasarkan kondisi seperti tersebut di atas memberi gambaran bahwa potensi sumberdaya alam termasuk sumberdaya sandang pangan masih sangat potensial untuk dapat dikembangkan dalam meningkatkan kemandirian dan kesejahteraan masyarakat, namun demikian fakta yang terjadi di masyarakat adalah terdapat beberapa lahan sawah masyarakat telah terjadi alih fungsi lahan secara masal.Untuk dapat menyebarluaskan informasi teknologi pertanian, hortikultura, perkebunan, peternakan dan teknologi tepat guna.

Berkembangnya masalah di desa tidak berarti seluruh komponen desa tidak berfungsi, malah dalam hal ini banyak komponen yang bisa di gali dan temukan dari kondisi fisik desa, menurunnya aktifitas dan pelaku pertanian tidak berarti hilangnya kesempatan desa untuk maju dan berkembang.

Kondisi ini terjadi di Desa Gunung Salak Kecamatan Selemadeg Timur Kabupaten Tabanan, banyak nya lahan tidak mampu di fungsikan sebagai lahan pertanian tidak menyurutkan masyarakat dalam membidik potensi lain yang dapat dikembangkan di wilayah Desa Gunung Salak.
Salah satu potensi yang dapat dikembangkan adalah desa wisata Gunung Salak, pengembangan desa wisata ini didasarkan oleh pemikiran yang mengacu pada penggalian potensi desa yang dapat meningkatkan peranan, fungsi, pendapatan dan budaya masayarakat di Desa Gunung Salak, tujuan dikembangkan desa wisata ini adalah untuk memajukan warga desa melalui berbagai potensi tanpa merusak alam dan lingkungan desa setempat, dengan mengoptimalkan peluang dan kekuatan yang terdapat di Desa Gunung Salak, dan menekan kelemahan serta hambatan yang muncul di desa Gunung Salak. Berdasarkan latar beakang diatas maka dapat dikembangkan Desa Wisata berbasis masyarakat.

\section{Tujuan}

Berdasarkan hasil observasi yang dilakukan di Desa Gunung Salak, menunjukkan bahwa pengembangan desa wissata di Desa Gunung Salak dilakukan dengan tujuan menggali potensi dan kekuatan yang terdapat di desa Gunung Salak dan menekan serta meminimalkan kelemahan dan hambatan yang terdapat di Desa Gunung Salak dalam upaya mewujudkan Desa Wisata Berbasis Masyarakat

\section{METODOLOGI}

\section{Observasi}

Observasi dilakukan di Desa Gunung Salak, Kecamatan Selemadeg Timur Kabupaten Tabanan, lokasi ini dipilih secara sengaja atas pertimbangan bahwa

1. Secara tofografi Desa Gunung Salak, Kecamatan Selemadeg Timur, Kabupaten Tabanan merupakan daerah berbukit dengan ketinggian \pm 300-400 meter diatas permukaan laut, curah hujan relatif sedang,

2. Penggunaan lahan di wilayah Desa Gunung Salak, tanah sawah 193 ha, pertanian lahan kering/perkebunan/tegalan 218,7 ha, hutan 0 ha dan perikanan dan peternakan $150 \mathrm{ha}$.

3. Jumlah penduduk Desa Gunung Salak pada Tahun 2014, mencapai sebanyak 1.668 jiwa.

4. Struktur penduduk menurut mata pencaharian menunjukkan bahwa sebagian besar penduduk menggantungkan sumber kehidupannya di sektor pertanian / Perkebunan $(86,08 \%)$, perdagangan $(0,54 \%)$ dan sektor lainnya seperti pegawai negeri, karyawan swasta dari berbagai sektor $(13,38$ $\%)$. 
5. Struktur perekonomian Desa Gunung Salak, masih bercorak agraris yang menitikberatkan pada sektor pertanian dan Perkebunan.

6. Dari Segi Potensi Pariwisata. Desa Gunung Salak yang Secara Topografi adalah daerah dengan perbukitan dan terasering yang sangat indah, Panorama Perkebunan yang sangat luas .sehingga sangat berpotensi untuk dikembangkan kepariwisataan seperti wisata Traking, Wisata Agro maupun wisata Relegius. Didesa Gunung salak judga terdapat lokasi yang sangat potensi seperti : Air Terjun Br. Kanciana, Goa Lindung di Br Gunung Salak, View Persawahan dan Perkebunan yang yang sangat indah, Areal Wisata treking /Oprouder, Sanggar Lukisan Kresnadana, Tari tradisional Okokan mebarung Br Apit Yeh Dan didukung oleh keramah tamahan penduduk.

\section{Analisis Data}

Analisis data yang digunakan adalah adalah SWOT yaitu metode perencanaan strategis yang digunakan untuk mengevaluasi kekuatan (strengths), kelemahan (weaknesses), peluang (opportunities), dan ancaman (threats) dalam suatu proyek atau suatu spekulasi bisnis. dianalisis dengan baik hubungan dari setiap aspek.Proses ini melibatkan penentuan tujuan yang spesifik dari spekulasi bisnis atau proyek dan mengidentifikasi faktor internal dan eksternal yang mendukung dan yang tidak dalam mencapai tujuan tersebut. Analisis SWOT dapat diterapkan dengan cara menganalisis dan memilah berbagai hal yang mempengaruhi keempat faktornya, kemudian menerapkannya dalam gambar matrik SWOT, di mana aplikasinya adalah bagaimana kekuatan (strengths) mampu mengambil keuntungan (advantage) dari peluang (opportunities) yang ada, bagaimana cara mengatasi kelemahan (weaknesses) yang mencegah keuntungan (advantage) dari peluang (opportunities) yang ada, selanjutnya bagaimana kekuatan (strengths) mampu menghadapi ancaman (threats) yang ada, dan terakhir adalah bagaimana cara mengatasi kelemahan (weaknesses) yang mampu membuat ancaman (threats) menjadi nyata atau menciptakan sebuah ancaman baru.

\section{HASIL DAN PEMBAHASAN}

Hasil

\section{Desa Wisata}

Desa Wisata Desa wisata adalah suatu bentuk integrasi antara atraksi, akomodasi dan fasilita s pendukung yang disajikan dalam suatu struktur kehidupan masyarakat yang menyatu dengan tata cara dan tradisi yang berlaku. Komponen Utama Desa Wisata meliputi : Akomodasi penginapan merupakan sebagian dari tempat tinggal para penduduk setempat dan atau unitunit yang berkembang atas konsep tempat tinggal penduduk dan Atraksi yaitu seluruh kehidupan keseharian penduduk setempat beserta setting fisik lokasi desa yang memungkinkan berintegrasinya wisatawan sebagai partisipasi aktif seperti : kursus tari, bahasa dan lain-lain yang spesifik ( Nuryanti, 1993).

Berdasarkan hasil observasi yang dilakukan di Desa Gunung Salak dapat diketahui bahwa komponen penting yang menjadi faktor utama penunjang pengembangan Desa Wisata berbasis pada potensi desa yaitu telah terdapat penginapan yaitu Eco Stay, dan beberapa vila kecil yang telah dimiliki penduduk Desa Gunung Salak. Eco stay merupakan penginapan yang dibangun berdasarkan kerjasama antara pengelola penginapan dengan warga setempat berupa lahan yang digunakan sebagai tempat untuk mendirikan penginapan Eco Stay tersebut.

Dari segi atraksi, Desa Gunung salak mempunyai berbagai atraksi yang dapat mendukung pengembangan desa wisata meliputi, bahasa lokal yang sering kali di ajarkan pada wisatawan yang berkunjung ke Desa Wisata Gunung Salak. Bahasa Lokasl di gunakan sebagai salah satu budaya yang unik dapat dikenalkan kepada wisatawan, mengingat di Desa Wisata Gunung Salak wisatawan akan berkeliling di sekitar desa dan ketemu dengan warga sekitar yang sering menyapa menggunakan bahasa lokal yaitu bahasa Bali. Sebagai bentuk atraksi bahasa digunakan sebagai objek untuk mengenalkan nama -nama benda, tempat dan kegiatan yang terdapat di Desa Gunung Salak.

\section{Kriteria Desa Wisata}

Pada pendekatan ini diperlukan beberapa kriteria yaitu : 
1. Atraksi wisata; yaitu semua yang mencakup alam, budaya dan hasil ciptaan manusia. Atraksi yang dipilih adalah yang paling menarik dan atraktif di desa.

2. Jarak Tempuh; adalah jarak tempuh dari kawasan wisata terutama tempat tinggal wisatawan dan juga jarak tempuh dari ibukota provinsi dan jarak dari ibukota kabupaten.

3. Besaran Desa; menyangkut masalahmasalah jumlah rumah, jumlah penduduk, karakteristik dan luas wilayah desa. Kriteria ini berkaitan dengan daya dukung kepariwisataan pada suatu desa.

4. Sistem Kepercayaan dan kemasyarakatan; merupakan aspek penting mengingat adanya aturan-aturan yang khusus pada komunitas sebuah desa. Perlu dipertimbangkan adalah agama yang menjadi mayoritas dan sistem kemasyarakatan yang ada.

5. Ketersediaan infrastruktur; meliputi fasilitas dan pelayanan transportasi, fasilitas listrik, air bersih, drainase, telepon dan sebagainya.

Masing-masing kriteria digunakan untuk melihat karakteristik utama suatu desa untuk kemudian menetukan apakah suatu desa akan menjadi desa dengan tipe berhenti sejenak, tipe one day trip atau tipe tinggal inap.

\section{Pendekatan Fisik Pengembangan Desa Wisata}

Pendekatan fisik merupakan solusi yang umum dalam mengembangkan sebuah desa melalui sektor pariwisata dengan menggunakan standar-standar khusus dalam mengontrol perkembangan dan menerapkan aktivitas konservasi.

1. Mengonservasi sejumlah rumah yang memiliki nilai budaya dan arsitektur yang tinggi dan mengubah fungsi rumah tinggal menjadi sebuah museum desa untuk menghasilkan biaya untuk perawatan dari rumah tersebut. Berdasarkan hasil pengamatan pengembangan model desa wisata Gunung Salak terletak di daerah pegunungan yaitu Gunung Batur, Bukit Pucak Sari dengan alam dan hamparan tera sering yang indah. aset wisata budaya berupa rumah-rumah tinggal yang memiliki arsitektur yang khas. Dan bagunan pura dengan arsitektur yang lokal Bali.

2. Mengonservasi keseluruhan desa dan menyediakan lahan baru untuk menampung perkembangan penduduk desa tersebut dan sekaligus mengembangkan lahan tersebut sebagai area pariwisata dengan fasilitasfasilitas wisata. Hasil observasi menunjukkan bahwa pendekatan pengembangan desa wisata jenis ini adalah Desa Wisata Sade, di Lombok.

3. Mengembangkan bentuk-bentuk akomodasi di dalam wilayah desa tersebut yang dioperasikan oleh penduduk desa tersebut sebagai industri skala kecil. Aset wisata di Desa Gunung salak ini sangat beragam antara lain : kerajinan anyaman bambu, tarian adat, rumah-rumah tradisional dan pemandangan ke arah laut dan bukit, sawah terasering yang indah. . Fasilitas-fasilitas wisata ini dikelola sendiri oleh penduduk desa setempat. Fasilitas wisata berupa akomodasi bagi wisatawan, kebun dan persawahan.

\section{Prinsip dasar dari pengembangan desa wisata}

Berdasarkan hasil observasi yang di lakukan di desa Gunung Salak dapat diketahui Bahwa :

1. Pengembangan fasilitas-fasilitas wisata dalam skala kecil beserta pelayanan di dalam atau dekat dengan desa.

2. Fasilitas-fasilitas dan pelayanan tersebut dimiliki dan dikerjakan oleh penduduk desa, salah satu bisa bekerja sama atau individu yang memiliki.

3. Pengembangan desa wisata didasarkan pada salah satu "sifat" budaya tradisional yang lekat pada suatu desa atau "sifat" atraksi yang dekat dengan alam dengan pengembangan desa sebagai pusat pelayanan bagi wisatawan yang mengunjungi kedua atraksi tersebut.

\section{Pembahasan}

1. Penentuan Peluang Dan Kekuatan Yang Terdapat Di Desa Gunung Salak Yang Dapat Di Kembangkan Sebagai Komponen Desa Wisata.

Analisis SWOT adalah identifikasi berbagai faktor secara sistematis untuk merumuskan strategi perusahaan. Analisis ini didasarkan pada logika yang dapat memaksimalkan kekuatan dan peluang ), namun secara bersamaan dapat meminimalkan kelemahan (Weaknesses) dan ancaman (Threats) (Freddy Rangkuti, 2005). 
Faktor internal adalah faktor -faktor berupa daya tarik wisata yang meliputi kekuatan dan kelemahan dalam menarik wisatawan di obyek Desa Gunung Salak. Analisis faktor internal yang meliputi kekuatan dan kelemahan dilakukan untuk mengetahui kondisi daerah tersebut secara internal. Menurut Pearce dan Robinson(2008), kekuatan merupakan sumber daya atau kapabilitas yang dikendalikan oleh atau tersedia bagi suatu perusahaan yang membuat perusahaan relative lebih unggul dibandingkan pesaingnya dalam memenuhi kebutuhan pelanggan yang dilayaninya.

Faktor eksternal adalah faktor -faktor berupa daya tarik wisata yang

meliputi peluang dan ancaman dalam menarik wisatawan di obyek wisata Desa Gunung Salak. Analisis eksternal yang meliputi peluang dan ancaman dilakukan untuk mengetahui posisi daerah dalam berhadapan dengan lingkungan eksternalnya. Menurut Pearce and Robinson(2008), peluang merupakan situasi utama yang menguntungkan dalam lingkungan suatu perusahaan, sedangkan ancaman adalah situasi utama yang tidak menguntungkan dalam lingkungan suatu perusahaan.

\section{Deskripsi Desa Gunung Salak Yang} Mempunyai Potensi Sebagai Desa Wisata

Dari Segi Potensi Pariwisata. Desa Gunung Salak yang Secara Topografi adalah daerah dengan perbukitan dan terasering yang sangat indah, Panorama Perkebunan yang sangat luas .sehingga sangat berpotensi untuk dikembangkan kepariwisataan seperti wisata Traking, Wisata Agro maupun wisata Relegius. Didesa Gunung salak judga terdapat lokasi yang sangat potensi seperti: Air Terjun Br. Kanciana, Goa Lindung di Br Gunung Salak, View Persawahan dan Perkebunan yang yang sangat indah, Areal Wisata treking /Oprouder, Sanggar Lukisan Kresnadana, Tari tradisional Okokan mebarung Br Apit Yeh Dan didukung oleh keramah tamahan penduduk.

Faktor- Faktor peluang Desa Gunung Salak dikembangan menjadi desa Wisata.

Berdasarkan hasil observasi dapat diketahui bahwa peluang yang menjanjikan desa Gunung
Salak dapat dikembangkan menjadi kawasan desa wisata yaitu :

a. Sektor pariwisata baru yang semakin berkembang dan diminati wisatawan di daerah natural pedesaan.

b. Dapat mengurangi pengangguran di Desa Gunung Salak, dengan membekali angkatan kerja di Desa Gunung Salak berbagai ketrampilan bersifat formal maupun informal yang dapat meningkatkan kinerja tenaga kerja desa Gunung Salak.

c. Pelestarian Budaya

d. Teknologi yang semakin berkembang

e. Opini positif dari wistawan ke wisatawan lainnya yang dapat meningkatkan jumlah kunjungan wisatawan ke Desa Wisata Gunung Salak.

Ancaman yang terdapat dengan berkembangnya wisata desa gunung salak

a. Persaingan antar objek pariwisata

b. Bencana alam

c. Jalan dan infrastruktur yang rusak

d. Kurangnya alat transfortasi umum

e. Promosi dari pemerintah daerah yang terbatas

Faktor internal yang menjadi kekuatan dalam pengebangan Desa Gunung salak sebgai Desa Wisata

Kekuatan yang di miliki DEsa Gunung Salak, berdasarkan hasil observasi yang dilakukan dapat diketahui meliputi :

a. Pemandangan yang indah sejuk dan asri

b. Objek wisata yang menarik dengan air terjun dan goa di sepanjang lintasan tracking

c. Keramahan masyarakat Desa Gunung Salak

d. Paket wisata yang lengkap dengan beberapa pilihan fasilitas (kuliner, edukasi, outbond dan lain-lain

e. Arena trailer lintas alam yang menantang.

Kelemahan yang ditemukan dalam pengembangan desa wisata Gunung Salak meliputi :

a. Kurangnya pergelaran seni budaya setempat

b. Promosi yang masih terbatas

c. Belum tersedianya toko souvenir lokal

d. Harga yang bersaing

e. SDM yang kualitas rendah 
Tabel. Faktor-faktor penentu pengembangan desa wisata berdasarkan SWOT

\begin{tabular}{|c|c|c|}
\hline $\begin{array}{c}\text { Eskternal Faktor } \\
\text { Evaluation } \\
\text { (EFE) }\end{array}$ & $\begin{array}{l}\text { Kekuatan (Strength) } \\
\text { a. Pemandanganyangindah sejuk dan } \\
\text { asri } \\
\text { b. Objek wisata yang menarik dengan } \\
\text { air terjun dan goa di sepanjang } \\
\text { lintasan tracking } \\
\text { c. Keramahan masyarakat Desa } \\
\text { Gunung Salak } \\
\text { d. Paket wisata yang lengkap dengan } \\
\text { beberapa pilihan fasilitas (kuliner, } \\
\text { edukasi, outbond dan lain-lain } \\
\text { e. Arena trailer lintas alam yang } \\
\text { menantang. }\end{array}$ & $\begin{array}{l}\text { Kelemahan( Weakness) } \\
\text { a. Kurangnya pergelaran } \\
\text { seni budaya setempat } \\
\text { b. Promosi yang masih } \\
\text { terbatas } \\
\text { c. Belum tersedianya toko } \\
\text { souvenir lokal } \\
\text { d. Harga yang bersaing } \\
\text { e. SDM yang kualitas } \\
\text { rendah }\end{array}$ \\
\hline $\begin{array}{l}\text { Peluang (opportunities) } \\
\text { a. Sektor pariwisata baru yang semakin berkembang dan } \\
\text { diminati wisatawan di daerah natural pedesaan. } \\
\text { b. Dapat mengurangi pengangguran di Desa Gunung Salak, } \\
\text { dengan membekali angkatan kerja di Desa Gunung Salak } \\
\text { berbagai ketrampilan bersifat formal maupun informal } \\
\text { yang dapat meningkatkan kinerja tenaga kerja desa } \\
\text { Gunung Salak. } \\
\text { c. Pelestarian Budaya } \\
\text { d. Teknologi yang semakin berkembang } \\
\text { e. Opini positif dari wistawan ke wisatawan lainnya yang } \\
\text { dapat meningkatkan jumlah kunjungan wisatawan ke } \\
\text { Desa Wisata Gunung Salak. }\end{array}$ & $\begin{array}{l}\text { SO } \\
\text { Menjaga kebersihan lingkungan dan } \\
\text { keindahan alam. } \\
\text { 2.Menjaga kelestarian joglo-joglo. } \\
\text { 3.Meningkatkan sarana-prasarana dan } \\
\text { fasilitas objek wisata. } \\
\text { 4.Menjaga nama baikd }\end{array}$ & $\begin{array}{l}\text { WO } \\
\text { 1.Menambah atraksi wisata. } \\
\text { 2.Meningkatkan promosi } \\
\text { menggunakan teknologi. } \\
\text { 3.Menambah toko souvenir. } \\
\text { 4.Memperhatikan harga } \\
\text { dalam fasilitas objek wisata. } \\
\text { 5.Meningkatkan kualitas } \\
\text { SDM dengan mengadakan } \\
\text { training. }\end{array}$ \\
\hline $\begin{array}{l}\text { Ancaman(Threat) } \\
\text { a. Persaingan antar objek pariwisata } \\
\text { b. Bencana alam } \\
\text { c. Jalan dan infrastruktur yang rusak } \\
\text { d. Kurangnya alat transfortasi umum } \\
\text { e. Promosi dari pemerintah daerah yang terbatas }\end{array}$ & $\begin{array}{l}\text { ST } \\
\text { Mengadakan kerja sama dengan } \\
\text { objek wisata yang berdekatan. } \\
\text { Menuntut kepedulian Pemerintah } \\
\text { dalam mengatasi kondisi jalan raya } \\
\text { yang rusak. } \\
\text { Menawarkanalattransportasi umum } \\
\text { yang langsung ke objek wisata }\end{array}$ & $\begin{array}{l}\text { WT } \\
\text { 1.Meningkatkan kualitas } \\
\text { keunggulan objek wisata } \\
\text { untuk mengatasi } \\
\text { persaingan pariwisata. } \\
\text { 2.Kerja sama dengan } \\
\text { Pemerintah untuk } \\
\text { membantu promosi atau } \\
\text { memasarkan objekwisata }\end{array}$ \\
\hline
\end{tabular}

\section{KESIMPULAN}

Berdasarkan hasil observasi yang dilakukan di Desa Gunung Salak, Kecamatan Selemadeg, Kabupaten Tabanan dapat disimpulkan bahwa:

1. Secara Eksternal dapat diketahui bahwa perkembangan objek wisata Desa Gunung Salak

2. Posisi internal Desa Gunung Salak memiliki posisi layak dikembangkan dan rentan terhadap kelemahan yang ada.

3. Tertimbang EFE yang menunjukkan bahwa faktor eksternal yang mempengaruhi secara langsung maupun tidak langsung terhadap peluang dan ancaman yaitu memiliki posisi yang sedang. Oleh karena itu, strategi yang cocok digunakan adalah strategi penetrasi pasar dan strategi pengembangan produk.

\section{REFERENSI}

Nuryanti, Wiendu. 1993. Concept, Perspective and Challenges, makalah bagian dari Laporan Konferensi Internasional mengenai Pariwisata Budaya. Yogyakarta: Gadjah Mada University Press. Hal. 2-3

Margono S. Drs. 2007. Metologi Penelitian Pendidikan Komponen MKDK. PT. Rineka Cipta Jakarta

Riduwan. 2004. Metode Riset. Jakarta : Rineka Cipta 
Sri Susanthi, K ., Drs. I Ketut Dunia, M.Erg. ., Luh Indrayani, S.Pd.,M.Pd. 2014. Analisis SWOT Untuk Meningkatkan Kunjungan Wisatawan di Desa Wisata Penglipuran Kecamatan Bangli Kabupaten Bangli002E

Strategi Pengembangan Desa Wisata (Studi Kasus Di Desa Candran) Strategies To Develop Tourism Vmustabsirah Program Studi Ilmu Ekonomi Fakultas Ekonomi,Universitas Muhammadiyah Yogyakarta, 2015

Widiyanto, Dodi, dkk. 2008. " Pengembangan Pariwisata Perdesaan (Suatu Usulan Strategi Bagi Desa Wisata Ketingan)". Jurnal Bumi Lestari, Vol.8 No. 2, Agustus 2008 